\title{
Estimation of Particle Size and Band Gap of Zinc Oxide Nanoparticle Synthesized by Chemical Precipitation Method
}

\author{
Surendra K. Gautam ${ }^{* 1}$, Bibek Sapkota ${ }^{1}$, Arun Bhujel ${ }^{1}$, Sitaram Bhattarai ${ }^{1,2}$ \\ ${ }^{1}$ Department of Chemistry, Tri-Chandra Campus, Tribhuvan University, Kathmandu, Nepal \\ ${ }^{2}$ Sogang University, Seoul, South Korea \\ *CorrespondingE-mail:sgautam2055@yahoo.com \\ (Received: March 22, 2020; Revised: June 22, 2020 \& Accepted: June 25, 2020)
}

\begin{abstract}
Zinc oxide $(\mathrm{ZnO})$ nanoparticles were synthesized by chemical precipitation method using $0.1 \mathrm{M}$ and $0.3 \mathrm{M}$ $\left[\mathrm{Zn}\left(\mathrm{NO}_{3}\right)_{2} \cdot 6 \mathrm{H}_{2} \mathrm{O}\right]$ and $\mathrm{Na}_{2} \mathrm{CO}_{3}$ solutions. The particle size and band gap of $\mathrm{ZnO}$ nanoparticles were estimated and effect of concentration on it was investigated. The synthesized nanoparticles were characterized by X-ray diffraction (XRD), Transmission electron microscopy (TEM), Energy dispersive X-ray spectroscopy (EDX), Fourier transform infrared spectroscopy (FTIR) and UV-visible spectroscopy. The XRD result revealed that synthesized $\mathrm{ZnO}$ nanoparticles have pure hexagonal wurtzite structure and the particle size varies from $27.0 \mathrm{~nm}$ to $29.9 \mathrm{~nm}$ estimated by using Debye-Scherrer's equation. The TEM image also projected the average particle size in the range of 20-30 $\mathrm{nm}$ and selected area electron diffraction (SAED) further verified the formation of hexagonal wurtzite structure. The FTIR result showed a broad absorption band related to Zn-O vibration band. The UV-visible absorption showed a red shift in the absorption edge with increasing concentration of $\mathrm{Zn}\left(\mathrm{NO}_{3}\right)_{2} \cdot 6 \mathrm{H}_{2} \mathrm{O}$ solution. The sizes and band gaps of $\mathrm{ZnO}$ nanoparticles increased and decreased, respectively with increasing concentration of $\mathrm{Zn}\left(\mathrm{NO}_{3}\right)_{2} \cdot 6 \mathrm{H}_{2} \mathrm{O}$ solution from $0.1 \mathrm{M}$ to $0.3 \mathrm{M}$.
\end{abstract}

Keywords: ZnO nanoparticles, chemical precipitation, UV-visible spectroscopy, XRD, EDX

\section{Introduction}

Zinc oxide is one of the most important binary (Group II-IV) semiconductor compounds with natural n-type electrical conductivity, a direct energy wide band gap of $3.37 \mathrm{eV}$ at the room temperature, and a large exciton binding energy $[1,2]$. It has been considered as a significant semiconducting material for a variety of applications due to its good transparency, wide band gap, strong room temperature luminescence, high optoelectronic efficiencies, high exciton binding energy and dielectric constant $[3,4]$. $\mathrm{ZnO}$ is considered as a promising material for electronic and optoelectronic device applications [5]. $\mathrm{ZnO}$ with controlled n-type conductivity has many important applications as transparent contacts and high electron mobility transistors (HEMTS) [6].

The $\mathrm{ZnO}$ nanoparticles can be used as gas sensors, photocatalysts for the removal of waste water pollutants, semiconductors, UV-photodiodes, rubber, medical and dental materials, pigments and coatings, ceramics, concrete, antibacterial and bactericide, and composites [7]. $\mathrm{ZnO}$ usually exists in two forms of structures as hexagonal wurtzite and cubic zinc blende among which wurtzite is the most stable and common $[8,9]$. This crystal structure can only be observed under electron microscopic examination. The bonding in $\mathrm{ZnO}$ is largely ionic as in most of Group II-VI materials which explains its strong piezoelectricity [10]. All those properties of $\mathrm{ZnO}$ are dependent to its average size and band gaps. Here, we report the estimation of average particle size and band gaps of $\mathrm{ZnO}$ nanoparticles and show their variation on changing the concentration of source compound $\left[\mathrm{Zn}\left(\mathrm{NO}_{3}\right)_{2} \cdot 6 \mathrm{H}_{2} \mathrm{O}\right]$. 


\section{Materials and Methods}

\section{Synthesis of $\mathrm{ZnO}$ nanoparticles}

$\mathrm{ZnO}$ nanoparticles can be synthesized through different methods like sol-gel method, hydrothermal method, mechanochemical method, solvothermal method, wet chemical method [11]. Simple chemical precipitation method is a widely used method for synthesis of zinc oxide which makes it possible to obtain a product with repeatable properties. This method is fast, spontaneous and limits the growth of the particles in the specified dimension [12].

$\mathrm{ZnO}$ nanoparticles were synthesized by chemical precipitation method using $0.1 \mathrm{M}$ and $0.3 \mathrm{M}$ $\left[\mathrm{Zn}\left(\mathrm{NO}_{3}\right)_{2} \cdot 6 \mathrm{H}_{2} \mathrm{O}\right]$ and $\mathrm{Na}_{2} \mathrm{CO}_{3}$ solutions. For this, solutions of $\left[\mathrm{Zn}\left(\mathrm{NO}_{3}\right)_{2} \cdot 6 \mathrm{H}_{2} \mathrm{O}\right]$ was taken in $1000 \mathrm{~mL}$ beaker and stirred it using magnetic stirrer for few minutes. The corresponding concentration of $\mathrm{Na}_{2} \mathrm{CO}_{3}$ solution was added to it drop-wise with vigorous stirring. The reaction between $\mathrm{Zn}\left(\mathrm{NO}_{3}\right)_{2}$ and $\mathrm{Na}_{2} \mathrm{CO}_{3}$ yields white precipitate of $\mathrm{ZnCO}_{3}$.

$\mathrm{Zn}\left(\mathrm{NO}_{3}\right)_{2}+\mathrm{Na}_{2} \mathrm{CO}_{3} \rightarrow \mathrm{ZnCO}_{3}+2 \mathrm{NaNO}_{3}$

The white precipitate of $\mathrm{ZnCO}_{3}$ formed in the solution was collected by the filtration process by using Whatman no. 42 filter paper. Thus, obtained precipitate was washed with ethanol and dried at 100 ${ }^{\circ} \mathrm{C}$ for 6 hours, then was annealed in air at $600{ }^{\circ} \mathrm{C}$ for 2 hours to obtain $\mathrm{ZnO}$ nanoparticles.

$\mathrm{ZnCO}_{3} \rightarrow \mathrm{ZnO}+\mathrm{CO}_{2}$

\section{Characterization}

The crystallite size and structure of $\mathrm{ZnO}$ nanoparticles were determined by XRD (Rigaku ultima IV model) employing $\mathrm{CuK} \alpha$ radiation $(\lambda=0.15406 \mathrm{~nm})$. The average crystalline size of the $\mathrm{ZnO}$ nanoparticles was estimated from the most intense XRD diffraction peak using Debye Scherrer's relation.

$\begin{array}{ll}\text { Average crystalline size } & \text { (D) }=\frac{0.9 \lambda}{\beta \cos \theta}\end{array}$

Where, $\lambda$ is the wave length of $X$-ray, $\beta$ is full width at half maximum (FWHM) of the most intense XRD peak expressed in radians and $\theta$ is Bragg's diffraction angle [13]. The crystalline structure of $\mathrm{ZnO}$ nanoparticles was confirmed from XRD peaks.

The average particle size and crystalline structure of $\mathrm{ZnO}$ nanoparticle were also determined from TEM images (Technai $\mathrm{G}^{2} 20$ electron Microscope) and SAED pattern. The assay of elemental compositions was estimated using EDX (Technai $\mathrm{G}^{2} 20$ electron Microscope). The formation of $\mathrm{ZnO}$ nanoparticles was confirmed with the help of FTIR (IRTracer-100, SHIMADZU) analysis and band gaps were determined from UV-Visible spectra (ELICO SL 177 spectrophotometer).

\section{Results and Discussion}

\section{XRD pattern}

Figures 1(a) and 1(b) are the XRD patterns of $\mathrm{ZnO}$ nanoparticle synthesized from $0.1 \mathrm{M}$ and $0.3 \mathrm{M}$ $\left[\mathrm{Zn}\left(\mathrm{NO}_{3}\right)_{2} \cdot 6 \mathrm{H}_{2} \mathrm{O}\right]$ solutions, respectively.
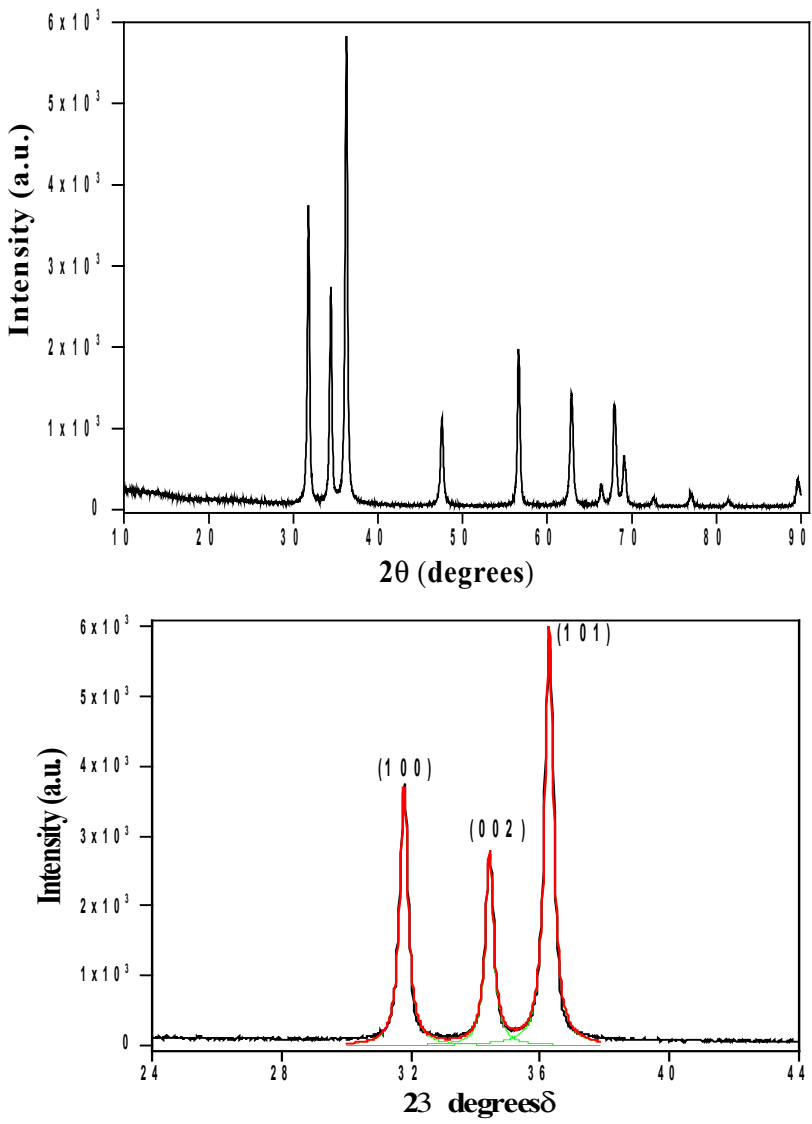

Figure 1(a): XRD pattern of the $\mathrm{ZnO}$ nanoparticle synthesized using $0.1 \mathrm{M}\left[\mathrm{Zn}\left(\mathrm{NO}_{3}\right)_{2} .6 \mathrm{H}_{2} \mathrm{O}\right]$ and $\mathrm{Na}_{2} \mathrm{CO}_{3}$ and corresponding Lorentzian fitting

Lorentzian profile was fitted to each sample to obtain FWHM value and the average particle size was calculated from Debye-Scherrer's equation as 27.0 $\mathrm{nm}$ and $29.9 \mathrm{~nm}$ synthesized from $0.1 \mathrm{M}$ and $0.3 \mathrm{M}$ precursors, respectively. The diffraction peaks at $2 \theta$ values of around $32^{\circ}, 34.5^{\circ}$ and $36.5^{\circ}$ correspond to (100), (002) and (101) crystalline planes of hexagonal structure (JCPDS card 36-1451) [5]. 

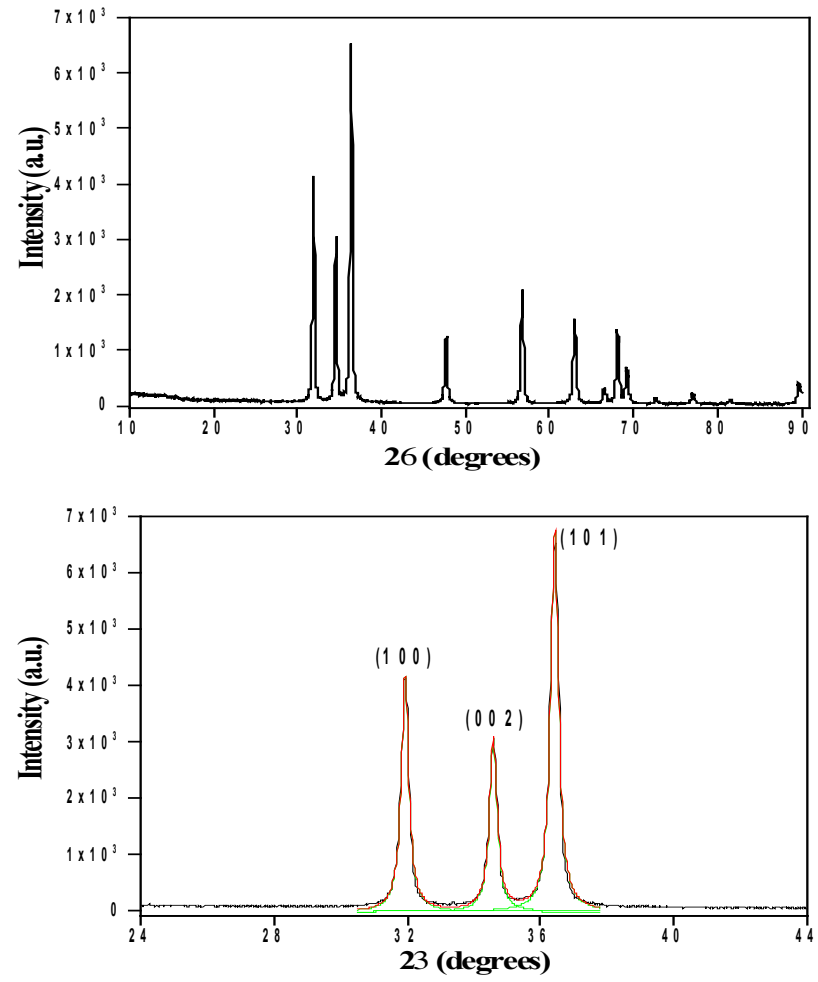

Figure 1(b): XRD pattern of the zinc oxide nanoparticle synthesized using 0.3M [ $\left.\mathrm{Zn}\left(\mathrm{NO}_{3}\right)_{2} .6 \mathrm{H}_{2} \mathrm{O}\right]$ and $\mathrm{Na}_{2} \mathrm{CO}_{3}$ and corresponding Lorentzian fitting.

\section{TEM analysis}

Figure 2 displays TEM micrographs of $\mathrm{ZnO}$ nanoparticles obtained from $0.1 \mathrm{M}$ solution of $\left[\mathrm{Zn}\left(\mathrm{NO}_{3}\right)_{2} \cdot 6 \mathrm{H}_{2} \mathrm{O}\right]$ and $\mathrm{Na}_{2} \mathrm{CO}_{3}$ showing spherical shape $[8,14]$. The average diameter was found to be in the range of (20-30) nm supported by the histogram and the Gaussian fitting spectra obtained from ImageJ software as shown in figures 3 (a) and 3(b), respectively.

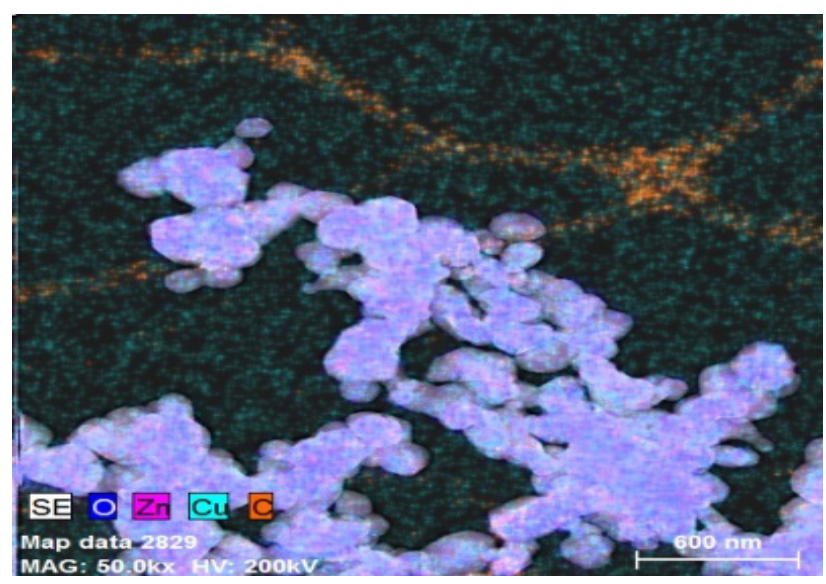

Figure 2: TEM image of $\mathrm{ZnO}$ nanoparticles prepared from $0.1 \mathrm{M}$ solution of $\left[\mathrm{Zn}\left(\mathrm{NO}_{3}\right)_{2} \cdot 6 \mathrm{H}_{2} \mathrm{O}\right]$ and $\mathrm{Na}_{2} \mathrm{CO}_{3}$
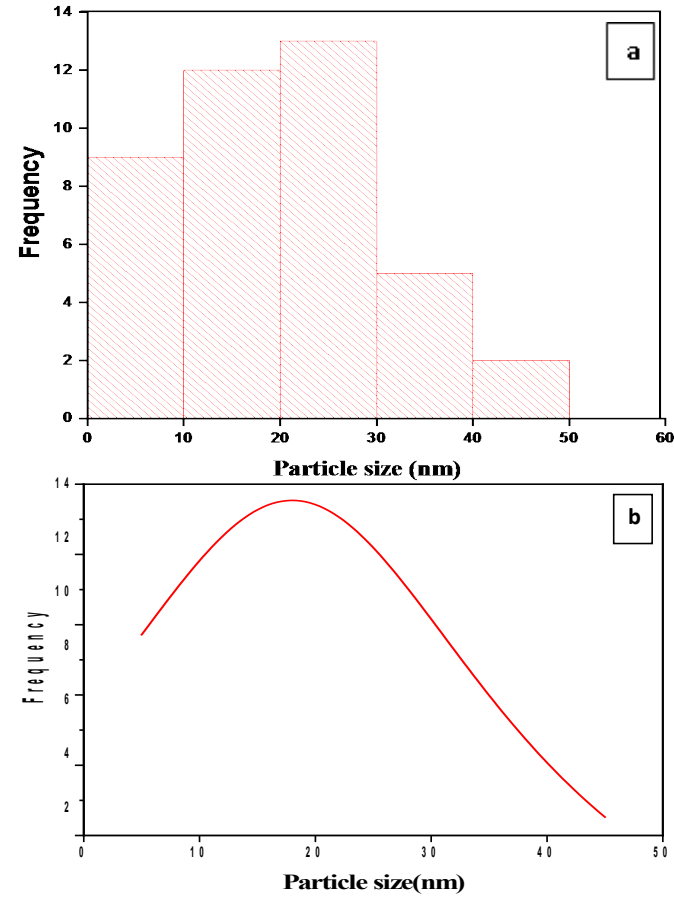

Figure 3: (a) Histogram and (b) Gaussian fitting corresponding curve obtained from ImageJ software

\section{Elemental analysis}

The TEM-EDX pattern is shown in figure 4 which confirms the synthesis of pure $\mathrm{ZnO}$ nanoparticles due to presence of only corresponding zinc and oxygen peaks.

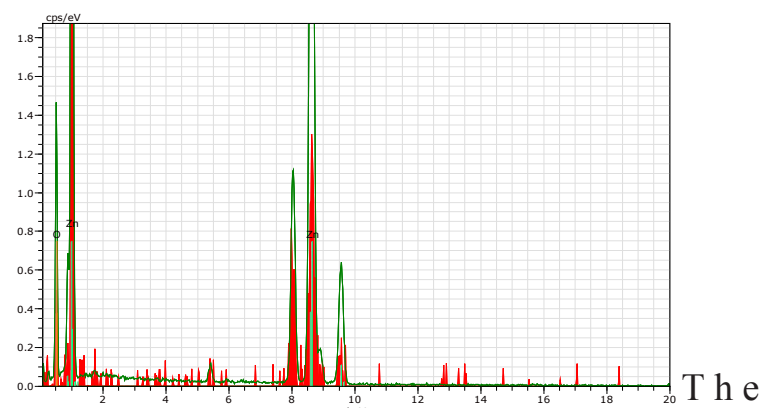

Figure 4: TEM-EDX spectra of $\mathrm{ZnO}$ nanoparticles obtained from $0.1 \mathrm{M}$ solution of $\left[\mathrm{Zn}\left(\mathrm{NO}_{3}\right)_{2} \cdot 6 \mathrm{H}_{2} \mathrm{O}\right]$ and $\mathrm{Na}_{2} \mathrm{CO}_{3}$

average atomic percentage ratio of $\mathrm{Zn}: \mathrm{O}$ atoms was found to be 63.3:36.7 as revealed in Table 1 .

Table 1: TEM-EDX result showing the composition of

\begin{tabular}{cc}
\multicolumn{2}{c}{$\mathrm{ZnO}$ nanoparticle } \\
\hline Elements & Atomic Weight \% \\
\hline Zinc & 63.30 \\
\hline Oxygen & 36.70 \\
\hline Total & 100.00
\end{tabular}

\section{SAED analysis}

The selected area electron diffraction (SAED) pattern of the $\mathrm{ZnO}$ nanoparticles is illustrated in the figure 5 . 


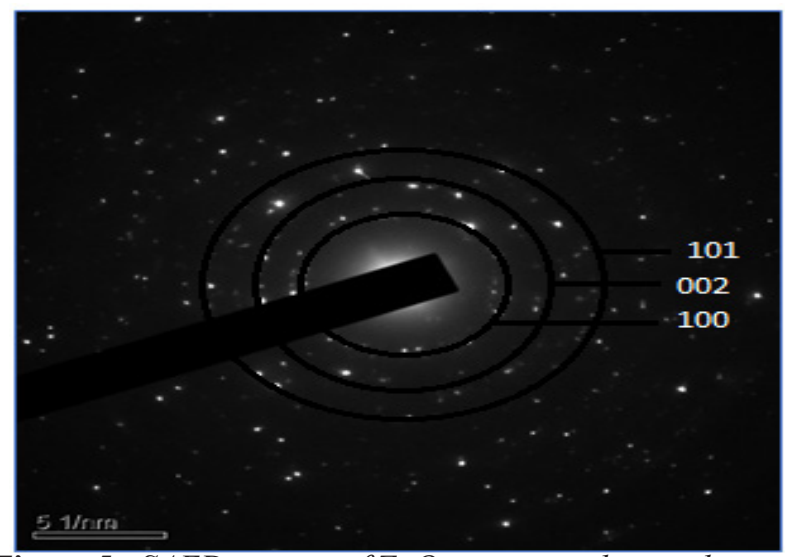

Figure 5: SAED pattern of $\mathrm{ZnO}$ nanoparticles synthesized from 0.1 M solutions of $\left[\mathrm{Zn}\left(\mathrm{NO}_{3}\right)_{2} .6 \mathrm{H}_{2} \mathrm{O}\right]$ solutionand $\mathrm{Na}_{2} \mathrm{CO}_{3}$ This pattern confirms the characteristic diffraction rings corresponding to (100), (002) and (101) indices of hexagonal wurtzite crystal structure of $\mathrm{ZnO}$ nanoparticles [3].

\section{FTIR analysis}

The FTIR spectra of $\mathrm{ZnO}$ nanoparticle synthesized using $0.1 \mathrm{M}\left[\mathrm{Zn}\left(\mathrm{NO}_{3}\right)_{2} \cdot 6 \mathrm{H}_{2} \mathrm{O}\right]$ and $\mathrm{Na}_{2} \mathrm{CO}_{3}$ solutions is shown in figure 6 . The spectrum showed the peak at $668 \mathrm{~cm}^{-1}$ is the infra-red band related to $\mathrm{Zn}-\mathrm{O}$ vibration [5].

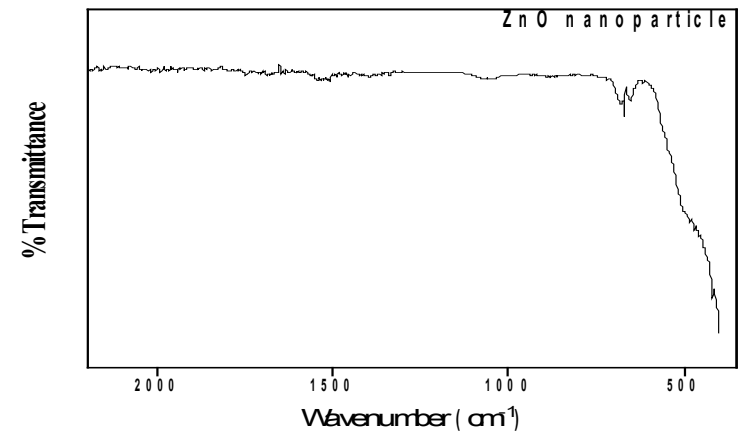

Figure 6: FTIR spectra of ZnO nanoparticle prepared using $0.1 \mathrm{M}\left[\mathrm{Zn}\left(\mathrm{NO}_{3}\right)_{2} .6 \mathrm{H}_{2} \mathrm{O}\right]$

\section{UV-Visible analysis}

Figure 7 (a) shows the UV-vis absorption spectra of the $\mathrm{ZnO}$ nanoparticles prepared using $0.1 \mathrm{M}$ and $0.3 \mathrm{M}$ solutions of $\left[\mathrm{Zn}\left(\mathrm{NO}_{3}\right)_{2} \cdot 6 \mathrm{H}_{2} \mathrm{O}\right]$. A broad absorption peak was observed in each spectrum at (360-380) $\mathrm{nm}$, which is the characteristic absorption band for the pure $\mathrm{ZnO}$ [15]. The spectra show the slight red shift from $371 \mathrm{~nm}$ to $379 \mathrm{~nm}$ as the concentration increased from $0.1 \mathrm{M}$ to $0.3 \mathrm{M}$. The band gap was calculated by extrapolating the curve drawn between $(\alpha h v)^{2}$ vs (hv) to the x-axis as shown in figure 7 (b)
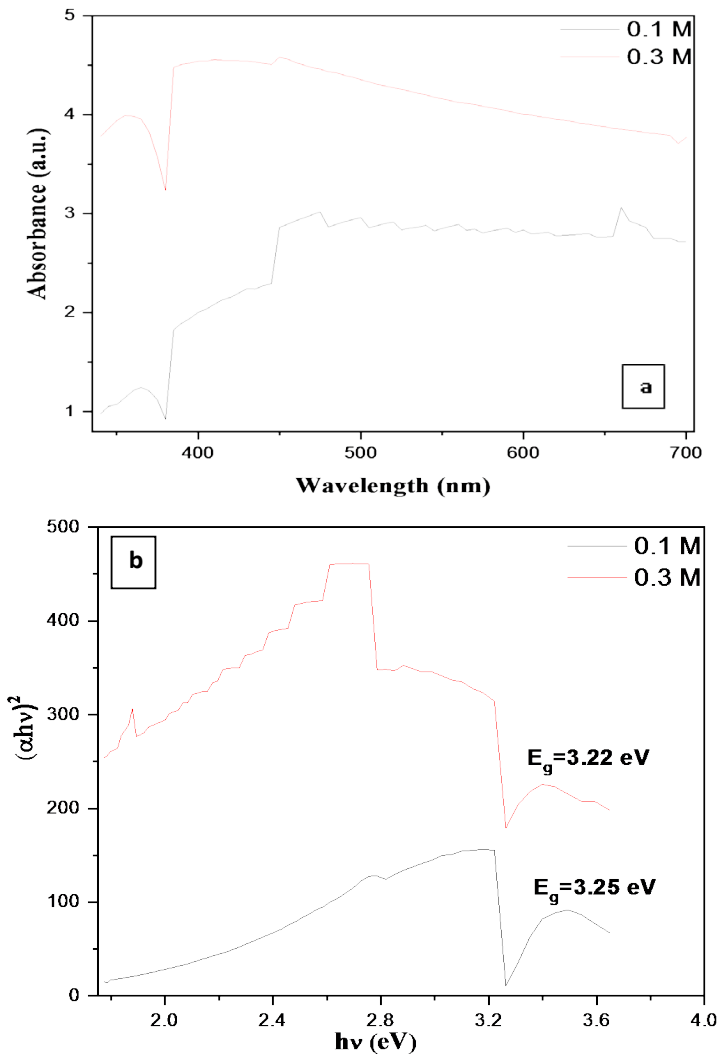

Figure 7: (a) UV-visible absorption spectra of $\mathrm{ZnO}$ nanoparticles synthesized using $0.1 \mathrm{M}$ and $0.3 \mathrm{M}$ solution of $\left[\mathrm{Zn}\left(\mathrm{NO}_{3}\right)_{2} .6 \mathrm{H}_{2} \mathrm{O}\right]$, (b) Corresponding plot of $(h v) v s(\alpha h \mu)^{2}$

and are found to be $3.25 \mathrm{eV}$ and $3.22 \mathrm{eV}$ for samples synthesized from $0.3 \mathrm{M}$ and $0.1 \mathrm{M}\left[\mathrm{Zn}\left(\mathrm{NO}_{3}\right)_{2} \cdot 6 \mathrm{H}_{2} \mathrm{O}\right]$ solutions, respectively. These band gaps fall under the reported value of $\mathrm{ZnO}$ nanoparticles [16,17].

\section{Conclusion}

$\mathrm{ZnO}$ nanoparticles have been successfully synthesized using $0.1 \mathrm{M}$ and $0.3 \mathrm{M}$ solutions of $\left[\mathrm{Zn}\left(\mathrm{NO}_{3}\right)_{2} \cdot 6 \mathrm{H}_{2} \mathrm{O}\right]$ and $\mathrm{Na}_{2} \mathrm{CO}_{3}$ by chemical precipitation method. The average particle size of $\mathrm{ZnO}$ nanoparticle increases and the band gap decreases with increase in the concentration $\left[\mathrm{Zn}\left(\mathrm{NO}_{3}\right)_{2} \cdot 6 \mathrm{H}_{2} \mathrm{O}\right]$ solution. The average particle size, purity of the synthesized $\mathrm{ZnO}$ nanoparticles obtained from XRD, EDX, TEM, SAED, FTIR and UV-VIS spectroscopy are quite supportive with each other. XRD pattern confirmed the pure hexagonal wurtzite structure which is further verified from SAED pattern. The average particle size obtained were $27.0 \mathrm{~nm}$ and $29.9 \mathrm{~nm}$ determined from XRD pattern using Debye-Scherrer's equation whereas band gap calculated as $3.25 \mathrm{eV}$ and $3.22 \mathrm{eV}$ as precursor concentration increased from $0.1 \mathrm{M}$ to $0.3 \mathrm{M}$, respectively. TEM image demonstrated the formation of spherical shaped $\mathrm{ZnO}$ nanoparticles 
while EDX, FTIR and UV-VIS spectra confirmed the formation of pure $\mathrm{ZnO}$ nanoparticles.

\section{Acknowledgements}

Authors are grateful to acknowledge Department of Chemistry, Tri-Chandra Campus and Central Department of Chemistry, Tribhuvan University for providing lab facilities and necessary materials. Thanks are also due to Ms. Indira Pokhrel, Center for Nanomaterials, Sogang University, S. Korea for TEM, SAED and EDX measurements and Dr. S.P. Singh, Sejong University, S. Korea for XRD data.

\section{References}

1. A. K. Barve, S. M. Gadegone, M. R. Lanjewar, and R. B. Lanjewar, Synthesis of $\mathrm{ZnO}$ nanomaterial by precipitation method and its characterization, International Journal of Chemical and Physical Sciences, 2015, 4, 432-439. (DOI: 10.1.1.678.8729)

2. R. Suntako, Effect of zinc oxide nanoparticles synthesized by a precipitation method on mechanical and morphological properties of the CR foam, Indian Academy of Sciences, 2015, 38 (4), 1033-1038.

3. A. J. Ahamed, and P. V. Kumar, Synthesis and characterization of $\mathrm{ZnO}$ nanoparticles by coprecipitation method at room temperature, Journal of Chemical and Pharmaceutical Research, 2016, 8 (5), 624-628. (DOI: 301b)

4. Z. L. Wang, Zinc oxide nanostructures: growth, properties and applications, Journal of Physics: Condensed Matter, 2004, 16, R829-R858. (DOI: 10.1088/0953-8984/16/25/R01)

5. N. A. Salahuddin, M. El-Kemary, and E. M. Ibrahim, Synthesis and characterization of $\mathrm{ZnO}$ nanoparticles via precipitation method: Effect of annealing temperature on particle size, Nanoscience and Nanotechnology, 2015, 5(4), 82-88. (DOI:10.5923/j.nn.20150504.02)

6. A. Janotti, and C. G. Van de Walle, Fundamentals of zinc oxide as semiconductor, Reports on Progress in Physics, 2009, 72, 1-30. (DOI: 10.1088/0034-4885/72/12/126501/meta)

7. P. Uikey, and K. Vishwakarma, Review of zinc oxide $(\mathrm{ZnO})$ nanoparticles applications and properties, International Journal of Emerging Technology in Computer Science \& Electronics, 2016, 21(2), 239-242.

8. S. L. Pal, U. Jana, P. K. Manna, G. P. Mohanta, and R. Manavalan, Nanoparticle: An overview of preparation and charaterization, Journal of Applied Pharmaceutical Science, 2011, 6, 228234.

9. S. K. Gautam, D. Pandey, S. N. Upadhyay, S. Anwar and N. P. Lalla, Unambiguous evidence for wurtzite phase in capped CdS qunatum dots, Solid State Communications, 2008, 146, 425-427. (DOI: 10.1016/j.scc.2008.03.020)

10. A.K. Arora, S. Devi, V.S. Jaswal, J. Singh, M. Kinger, and V.D. Gupta, Synthesis and characterization of $\mathrm{ZnO}$ nanoparticles, Oriental Journal of Chemistry, 2014, 30(4), 1671-1679. (DOI: 10.13005/ojc/300427)

11. B. S. Murty, P. Shankar, R. Baldev, B. B. Rath and J. Murday, Text Book of Nanoscience and Nanotechnology, University Press Private Limited, Himayatnagar, India, 2012.

12. A. Kolodziejczak-Radzimska, and T. Jesionowski, Zinc oxide from synthesis to application: A Review, Materials, 2014, 7, 2833-2881. (DOI: 10.3390/ma7042833)

13. S. Dhungana, B. R. Poudel and S.K. Gautam, Synthesis and characterization of ZnTe nanopartilces, Nepal Journal of Science and Technology, 2016, 17(1), 1-3.

14. A. Regmi, J. Bhandari, S. Bhattarai and S. K. Gautam, Synthesis, characterization and antimicrobial activity of cuprous oxide $\left(\mathrm{Cu}_{2} \mathrm{O}\right)$ nanoparticles, Journal of Nepal Chemical Society, 2019，40, 5-10. (DOI: https://doi.org:10.3126/ jncs.v40i0.27271)

15. S. R. Brintha and M. Ajitha, Synthesis and characterization of $\mathrm{ZnO}$ nanoparticles via aqueous solution, sol-gel and hydrothermal methods, IOSR Journal of Applied Chemistry, 2015, 8 (11), 66-72. (DOI: 10.9790/5736-081116672)

16. J. Jeevandam, A. Barhoum, Y. S. Chan, A. Dufresne, and M. K. Danquah, Review on nanoparticles and nanostructured materials: history, sources, toxicity and regulations, Beilstein Journal of Nanotechnology, 2018, 1-25. (DOI: 10.3762/bjnano.9.98.)

17. D. S. Bai, V. R. Kumar and R. P. Suvarna, Synthesis and characterization of zinc oxide nanoparticles by solution combustion method: DC Conductivity studies, Indian Journal of Advances in Chemical Sciences, 2017, 5(3), 137-141. (DOI: 10.22607/ IJACS.2017.503004) 